\title{
KEPUASAN HIDUP MAHASISWA TINGKAT PERTAMA: KAITANNYA DENGAN KARAKTER MAHASISWA DAN GAYA PENGASUHAN ORANG TUA
}

\author{
Dyanza Sri Novianti ${ }^{1 *}$, Alfiasari ${ }^{1}$ \\ ${ }^{1}$ Departemen IImu Keluarga dan Konsumen, Fakultas Ekologi Manusia, Institut Pertanian Bogor, Bogor 16680, \\ Indonesia
}

*)E-mail: dyanzasn@gmail.com

\begin{abstract}
Abstrak
Mahasiswa tingkat pertama yang tinggal di asrama menghadapi masa transisi penting menuju kematangan periode dewasa. Salah satu hal penting dalam menuju kedewasaan adalah kemampuan seseorang dalam menilai kepuasan hidupnya. Penelitian ini bertujuan untuk menganalisis pengaruh karakteristik mahasiswa, karakteristik keluarga, gaya pengasuhan, dan karakter terhadap kepuasan hidup mahasiswa. Penelitian ini dilakukan di salah satu kampus di Bogor, Jawa Barat yang menerapkan mahasiswa tingkat pertamanya untuk tinggal di asrama. Contoh penelitian ini terdiri dari 102 mahasiswa tingkat pertama yang dipilih menggunakan metode multi-stage random sampling berdasarkan kelas kuliah. Gaya pengasuhan ayah dan ibu yang dipersepsikan oleh mahasiswa diukur dengan menggunakan instrumen Parent as Social Context Questionnaire (PASCQ-final version) dari Skinner, Sandy, dan Tatiana (2005). Karakter mahasiswa diukur dengan menggunakan instrumen Value in Action Inventory of Strengths (VIA-IS). Kepuasan hidup diukur dengan menggunaka instrument West (2006) yaitu penilaian mahasiswa terhadap kepuasan beberapa aspek hidupnya. Hasil uji beda menemukan bahwa terdapat perbedaan signifikan antara gaya pengasuhan ayah dan ibu pada dimensi kehangatan. Hasil analisis regresi menemukan bahwa gaya pengasuhan ayah berpengaruh signifikan positif terhadap karakter mahasiswa tingkat pertama. Selanjutnya, ditemukan bahwa karater berpengaruh positif signifikan terhadap kepuasan hidup mahasiswa tingkat pertama.
\end{abstract}

Kata kunci: gaya pengasuhan ayah, gaya pengasuhan ibu, karakter, kepuasan hidup

\section{Life Satisfaction of First Grade College Student: Relationship with Characters and Parenting Styles}

\begin{abstract}
The first-grade college students who were living in the dormitory face transitional period toward the adult period. Therefore, it needed the ability to measure his life satisfaction. This study aimed 1) to analyze the differences between maternal and paternal parenting styles; 2) to analyze the influence of college student characteristic, family characteristic and parenting style toward college student character; and 3) to analyze the influence of college student characteristic, family characteristic, parenting style, and character toward life satisfaction. This research was conducted in Bogor Agricultural University, Bogor City, West Java Province. The sample consists of 102 first-grade college student which selected by multistage random sampling method. Maternal and paternal parenting styles perceived by students are measured using the Parent as Social Context Questionnaire (PASCQfinal version) instrument of Skinner, Sandy, and Tatiana (2005). College student characters are measured using the Value in Action Inventory of Strengths (VIA-IS) instrument. Meanwhile, life satisfaction was measured using an instrument developed by West (2006). Independent sample t-test found that there was a significant difference between maternal and paternal parenting styles on the warmth dimension. Regression analysis found that parenting style had a significant positive effect toward college student character. Regression analysis also found that character had a significant positive effect toward life satisfaction of college student.
\end{abstract}

Keywords: character, life satisfaction, maternal parenting stlye, paternal parenting stlye

\section{PENDAHULUAN}

Masa perkuliahan bagi sebagian orang menjadi masa transisi penting dalam hidupnya, apalagi transisi dari masa SMA ke kehidupan perguruan tinggi mensyaratkan mahasiswa tinggal di asrama di tahun pertamanya. Setelah sebelumnya mahasiswa terbiasa tinggal bersama orang tua, transisi mahasiswa dalam menyesuaikan kehidupan perkuliahan harus disertai dengan keberhasilan mahasiswa dalam menyesuaikan kehidupan di asraama. Tingkat pertama masa perkuliahan merupakan masa peralihan dari usia remaja akhir ke dewasa awal. Pada periode ini ketika mahasiswa memasuki usia dewasa awal, 
tugas perkembangan di periode remaja seharusnya sudah tercapai dan perlu mempersiapkan diri untuk tugas perkembangan dewasa awal. Tugas perkembangan dewasa awal diantaranya adalah mulai bekerja, memegang tanggung jawab sebagai bagian dari masyarakat, dan menemukan kelompok sosial yang sesuai (Hurlock, 2009). Namun, tidak semua individu dewasa awal dapat memenuhi tugas perkembangannya. Hal ini menyebabkan individu tersebut cenderung tidak puas dengan kehidupannya. Kondisi ini meningkatkan kemungkinan terjadinya stres atau depresi seperti yang dikatakan oleh Furr et al. (1991) dalam Park, Peterson, dan Seligman (2004) bahwa individu dengan kepuasan hidup yang rendah memiliki resiko lebih tinggi mengalami masalah psikologis seperti depresi. Penelitian Ehrlich dan Isaacowitz (2002) menemukan bahwa pada usia 18-25 tahun, individu lebih memiliki resiko yang tinggi mengalami depresi dibandingkan dengan kelompok usia lainnya.

Depresi merupakan salah satu penyebab seseorang berkeinginan untuk bunuh diri (Dewi \& Hamidah 2013). Menurut World Health Organization (WHO), diperkirakan di seluruh dunia tiap 40 detik ada satu individu yang meninggal bunuh diri. Di Indonesia, kasus bunuh diri telah mencapai 9.105 pada tahun 2012 dengan perhitungan sekitar 3,6 per 100.000 penduduk (WHO, 2014). Oleh karenanya, untuk menurunkan resiko terjadinya masalah psikologis pada seseorang khususnya pada periode remaja awal sebagai persiapan memasuki periode dewasa, kepuasan hidup menjadi salah satu faktor penting yang perlu dikaji.

Kepuasan hidup merupakan suatu kondisi yang meliputi kepuasan individu terhadap hidupnya saat ini dan terbagi menjadi dua jenis yaitu kepuasan hidup secara umum dan kepuasan pribadi seperti cinta, pernikahan, persahabatan, dan lainnya (Nisfiannor, Rostiana, \& Puspasari, 2004). Asih, Yuliadi, dan Karyanta (2015) menyebutkan bahwa kepuasan hidup dipengaruhi oleh faktor internal seperti karakteristik indvidu dan faktor eksternal yaitu dari lingkungan. Seligman (2002) dalam Wijayanti dan Nurwiyan (2010) yang membuktikan bahwa karakteristik keluarga dapat memengaruhi kepuasan hidup seseorang dan kepuasan hidup seseorang dapat dilihat dari karakteristik yang dimilikinya (Coutinho \& Woolery, 2004). Lebih lanjut, penelitian West (2006) membuktikan bahwa karakter (character strength) yang dimiliki dapat memprediksi kepuasan hidup seseorang. Chung (2008) juga menegaskan bahwa terdapat hubungan antara karakter dengan kepuasan hidup. Seligman dan Peterson (2004) telah mengidentifikasi 24 subdimensi karakter dalam klasifikasi Values in Action (VIA) yang terdiri dari beberapa dimensi karakter seperti bijak (wisdom and knowledge), teguh hati (courage), manusiawi (humanity), adil (justice), sederhana (temperance), dan transendensi (transcendence). Setiap individu akan mempunyai kekuatan karakter yang berbeda-beda. Kekuatan karakter yang dimiliki tersebut harus dapat dikembangkan dan dimanfaatkan untuk meningkatkan kualitas hidup seseorang. Karakter seseorang dibentuk melalui tiga aspek yaitu pengetahuan tentang moral (moral knowing), sikap dan perasaan tentang moral (moral feeling), dan perilaku moral (moral action). Selain tiga aspek moral dalam membentuk karakter, Lickona (2012) dalam Dalmeri (2014) juga menjelaskan tentang mendidik dengan cara menanamkan kebiasaan pada anak atau internalisasi karakter yang memiliki tiga unsur utama yaitu mengetahui kebaikan (knowing the good), mencintai kebaikan (desiring the good), dan melakukan kebaikan (doing the good).

Karakter merupakan sesuatu yang dimiliki setiap individu dengan keunikannya masingmasing (nature) dan dipengaruhi juga oleh lingkungan tempat dia dibesarkan (nurture). $\mathrm{Hal}$ ini termasuk ke dalam pandangan organismik yang menganggap bahwa manusia tumbuh dan berkembang karena genetik (innate) dan proses pembelajaran (learning process). Keluarga terutama orang tua, termasuk ke dalam lingkungan mikrosistem yang memiliki pengaruh paling besar dalam pembentukan karakter anak melalui pengasuhan. Dalam mengasuh anak, setiap orang tua pasti memiliki gaya yang berbeda atau kecenderungan pada beberapa gaya pengasuhan sesuai dengan budaya dan riwayat gaya pengasuhan yang dialami orang tua tersebut (Amelia, 2013). Model motivasi Skinner, Sandy, dan Tatiana (2005) menjelaskan tentang enam dimensi (kehangatan, penolakan, keteraturan, ketidakteraturan, dukungan, dan paksaan) dalam pengasuhan yang menyatakan bahwa anak-anak termotivasi oleh tiga kebutuhan primer. Pertama, anak-anak harus merasa bahwa mereka berada dan dipelihara oleh kehangatan orang tua. Kedua, anak-anak perlu mengetahui batasan diri mereka yang tergambarkan melalui aturan-aturan dari orang tua. Ketiga, anak-anak ingin dilihat sebagai individu unik yang didorong oleh dukungan orang tua. 
Penelitian-penelitian terdahulu telah menggunakan variabel gaya pengasuhan untuk mengidentifikasi praktek pengasuhan orang tua. Penelitian yang dilakukan Amelia (2013) membuktikan bahwa gaya pengasuhan orang tua yang memberikan kehangatan dengan tetap memberikan batasan dapat memengaruhi kualitas anak, khususnya status identitas anak. Temuan tersebut sejalan dengan dimensi pengasuhan positif Skinner, Sandy, dan Tatiana (2005) yang menunjukkan adanya korelasi dengan pengaturan diri, kompetensi akademik, sosial, prestasi akademik, komitmen untuk sekolah, kontrol diri, dan harga diri. Namun ketika anak mengalami penolakan orangtua, kekacauan dan pemaksaan, dan tidak memperoleh dukungan, anak-anak tersebut cenderung menghindari untuk bersosialisasi, memiliki hasil akademik negatif, terlibat dalam penggunaan narkoba lebih sering, dan memiliki masalah perilaku (Skinner, Sandy, \& Tatiana 2005). Penelitian lainnya yang ditemukan oleh Pasaribu, Hastuti, dan Alfiasari (2013) adalah gaya pengasuhan dengan kehangatan tinggi namun tuntutan perilaku rendah menyebabkan rendahnya karakter remaja.

Gaya pengasuhan tentunya melibatkan ayah dan ibu sebagai tokoh utama yang memiliki pengaruh bagi perkembangan anak. Ayah dan ibu memiliki latar belakang yang berbeda dan memiliki riwayat pengasuhan yang berbeda pula. Hal ini membuat ayah dan ibu cenderung mengasuh anak dengan cara yang sama seperti yang pernah dialaminya dulu. Ayah dan ibu diharapkan dapat memberikan model pengasuhan yang lengkap dan dapat saling melengkapi (Nurhidayah, 2008). Penelitian yang dilakukan oleh Krisnatuti dan Muharrifah (2010) menunjukkan bahwa semakin dekat hubungan anak dengan ayah semakin tinggi anak memprioritaskan tujuan hidupnya yang memungkinkan tercapainya kepuasan hidup anak.

Sementara itu, hasil penelitian Dewi dan Basti (2015) mengatakan bahwa ibu memiliki pengaruh yang lebih besar dikarenakan kelekatan yang dibangun sejak kecil sehingga gaya pengasuhan ibu memengaruhi kepuasan yang dimiliki anak. Gogolinski (2012) mengatakan bahwa anak yang memiliki ayah/ibu yang memberikan kehangatan dan keteraturan lebih memiliki kepuasan hidup yang tinggi dibandingkan anak yang ayah dan ibunya tidak menggunakan gaya pengasuhan positif sama sekali. Selain itu, hasil penelitian Gogolinski (2012) membuktikan bahwa perbedaan gaya pengasuhan antara ayah dan ibu dapat membuat anak mempersepsikan kurangnya dukungan yang diberikan keluarga padanya.

Oleh karenanya, penelitian ini selanjutnya ingin membedakan gaya pengasuhan yang diterapkan ayah dan ibu sehingga dapat diidentifikasi lebih lanjut mengenai dampaknya pada anak. Penelitian ini berusaha untuk mengungkap keterkaitan antara gaya pengasuhan yang dirasakan oleh mahasiswa dengan menggunakan Model Motivasi Skinner, Sandy, dan Tatiana (2005), karakter yang dimiliki mahasiswa, dan bagaimana pengaruhnya terhadap kepuasan hidup yang dirasakan mahasiswa. Berdasarkan rumusan latar belakang yang telah diuraikan maka penelitian ini bertujuan: 1) menganalisis perbedaan gaya pengasuhan ayah dan ibu; 2) menganalisis pengaruh karakteristik mahasiswa, karakteristik keluarga dan gaya pengasuhan terhadap karakter mahasiswa; dan 3) menganalisis pengaruh karakteristik mahasiswa, karakteristik keluarga, gaya pengasuhan, dan karakter mahasiswa terhadap kepuasan hidup mahasiswa.

\section{METODE}

Penelitian ini menggunakan desain cross sectional study. Penelitian ini dilakukan di salah satu perguruan tinggi negeri di Bogor, Jawa Barat. Lokasi ini dipilih secara purposive (sengaja) dengan pertimbangan bahwa kampus IPB menerima mahasiswa dari seluruh Indonesia dengan latar belakang karakteristik keluarga yang beragam dan juga mensyaratkan mahasiswa untuk tinggal di asrama dalam tahun pertamanya. Pelaksanaan penelitian dari dilaksanakan dari Desember 2015 sampai dengan April 2016.

Populasi penelitian ini adalah mahasiswa tingkat pertama di perguruan tinggi terpilih yang memiliki orang tua lengkap. Contoh dari penelitian ini terdiri dari 102 mahasiswa yang dipilih menggunakan metode multi-stage random sampling. Tahap pertama yang dilakukan adalah mengacak dua kelas dari 31 kelas tingkat pertama. Setelah mendapatkan dua kelas yaitu P09 dan Q03, tahap berikutnya adalah mengacak 120 mahasiswa dari total 213 mahasiswa di kedua kelas tersebut. Berdasarkan rumus Slovin, jumlah contoh minimal yang diperlukan adalah sebanyak 98 orang dan penelitian ini menetapkan menggunakan jumlah contoh sebanyak 120 orang. Setelah proses cleaning data hanya 102 responden yang digunakan dalam 
penelitian ini dikarenakan drop out karena ketidaklengkapan data.

Data yang dikumpulkan dalam penelitian ini merupakan data primer yang terdiri atas karakteristik mahasiswa, karakteristik keluarga, gaya pengasuhan ayah dan ibu berdasarkan persepsi mahasiswa, karakter mahasiswa, dan kepuasan hidup mahasiswa. Pengumpulan data menggunakan metode self-administered dengan alat bantu kuesioner. Karakteristik mahasiswa terdiri atas usia dan jenis kelamin. Karakteristik keluarga terdiri atas usia ayah, usia ibu, lama pendidikan ayah, lama pendidikan ibu, status pekerjaan ayah, status pekerjaan ibu, pendapatan keluarga, dan besar keluarga.

Kuesioner pada penelitian ini menggunakan tiga instrumen yaitu Parent as Social Context Questionnaire (PASCQ), Value in Action Inventory of Strengths (VIA-IS), dan instrumen kepuasan hidup oleh West (2006). Gaya pengasuhan ayah dan ibu yang dipersepsikan oleh contoh menggunakan instrumen Parent as Social Context Questionnaire (PASCQ-final version) dari Skinner, Sandy, dan Tatiana (2005) dengan dimensi kehangatan (warmth), penolakan (rejection), keteraturan (structure), ketidakteraturan (chaos), dukungan (autonomy support), dan paksaan (coercion) dalam 24 pernyataan. Instrumen diukur dengan empat poin skala Likert, yaitu sangat tidak menggambarkan (skor 1), sedikit menggambarkan (skor 2), menggambarkan (skor 3), dan sangat menggambarkan (skor 4). Hasil uji reliabilitas menemukan Cronbach's Alpha gaya pengasuhan ayah sebesar 0,796 dan Cronbach's Alpha gaya pengasuhan ibu sebesar 0,737 .

Karakter contoh diukur menggunakan instrumen Value in Action Inventory of Strengths (VIA-IS) yang mencakup 6 dimensi yaitu bijak (wisdom and knowledge), teguh hati (courage), manusiawi (humanity), adil (justice), sederhana (temperance), dan transendensi (transcendence) yang terbagi menjadi 24 subdimensi dengan diwakili oleh lima pernyataan per subdimensi untuk mengukur karakter mahasiswa. Instrumen ini menggunakan lima poin skala Likert sangat seperti saya (skor 1), seperti saya (skor 2), netral (skor 3), tidak seperti saya (skor 4), dan sangat tidak seperti saya (skor 5) dengan Cronbach's Alpha sebesar 0,943. Dalam pengisian kuesioner, mahasiswa melakukan pengisian online melalui laman www.viacharacter.org dan sebelumnya peneliti telah melakukan komunikasi dengan pihak VIA
Institute on Character untuk memperoleh ijin pengisian kuesioner VIA untuk keperluan penelitian.

Kepuasan hidup diukur menggunakan instrumen yang dibuat oleh West (2006) dengan 11 pernyataan namun dalam penelitian ini hanya menggunakan 8 pernyataaan mengingat subjek penelitian yang dinilai masih pada periode remaja akhir sehingga dimensi karier dan pekerjaan belum dapat diukur. Kepuasan hidup yang diukur dalam instrumen ini mencakup kepuasan hidup responden terhadap diri sendiri, teman, lingkungan, dan pendidikan yang diukur dengan 7 poin skala Likert yaitu sangat tidak puas (skor 1), tidak puas (skor 2), sedikit tidak puas (skor 3 ), netral (skor 4), sedikit puas (skor 5), puas (skor 6), dan sangat puas (skor 7). Berdasarkan hasil analisis, Cronbach's Alpha kepuasan hidup adalah sebesar 0,728.

Data diolah menggunakan Microsoft Excel dan Statistical Package for Social Science (SPSS) for Windows. Data diperoleh dari kuesioner diolah melalui tahap editing, coding, scoring, dan cleaning data.Selanjutnya dilakukan analisis data secara deskriptif dan inferensia. Analisis data yang digunakan dalam penelitian ini adalah analisis deskriptif (nilai minimum, maksimum, standar deviasi, rata-rata), uji beda untuk menganalisis perbedaan gaya pengasuhan ayah dan ibu, serta uji regresi berganda untuk menganalisis pengaruh karakteristik mahasiswa, karakterisitk keluarga, gaya pengasuhan, dan karakter mahasiswa terhadap kepuasan hidup mahasiswa. Penelitian ini menggunakan uji asumsi klasik normalitas, autokorelasi, multikolinieritas, dan heterokedastisitas sebelum data diuji regresi linear berganda.

\section{HASIL}

\section{Karakteristik Mahasiswa}

Karakteristik mahasiswa yang diukur adalah usia, jenis kelamin, dan jumlah saudara kandung. Hasil analisis menemukan dari 102 responden mahasiswa, jumlah mahasiswa lakilaki adalah 38 orang $(37,3 \%)$ dan mahasiswa perempuan berjumlah 64 orang $(62,7 \%)$. Usia mahasiswa berkisar antara 18 hingga 23 tahun. Persentase terbesar, yaitu sebanyak 71,6 persen mahasiswa berusia 19 tahun. Jumlah saudara kandung yang dimiliki oleh mahasiswa antara 0 hingga 7 orang. Hasil penelitian menunjukkan bahwa lebih dari sepertiga mahasiswa $(38,2 \%)$ memiliki dua saudara kandung. 


\section{Karakteristik Keluarga}

Hasil analisis menemukan sebagian besar usia ayah $(97,1 \%)$ dan ibu $(90,2 \%)$ termasuk kategori dewasa madya (Papalia, Olds, \& Feldman, 2009) yaitu antara 41 hingga 65 tahun. Rata-rata usia ayah dan ibu adalah 50,8 tahun dan 46,4 tahun. Sementara itu, rata-rata lama pendidikan ayah dan ibu dalah 12 tahun. Sebanyak masing-masing sepertiga ayah dan ibu tingkat pendidikannya adalah tamat SMA $(39,2 \%)$. Selanjutnya terdapat 31,4 persen ayah dan 25,5 persen ibu tingkat pendidikannya diatas D3. Hasil penelitian menemukan bahwa proporsi terbesar jenis pekerjaan ayah terdiri atas wirausaha atau pedagang (27,5\%) dan PNS (23,5\%) sedangkan lebih dari setengah ibu $(55,9 \%)$ tidak bekerja. Adapun proporsi terbesar jenis pekerjaan ibu yang bekerja adalah PNS $(13,7 \%)$ dan wirausaha/pedagang (12,7\%). Pendapatan yang diterima keluarga beragam dari rentang antara Rp400.000,00 hingga Rp25.000.000,00 per bulan. Rata-rata pendapatan keluarga adalah sebesar Rp4.590.118,00.

\section{Gaya Pengasuhan}

Berdasarkan pada model motivasi, Skinner, Sandy, dan Tatiana (2005) mengklasifikasikan gaya pengasuhan menjadi tiga dimensi positif yaitu kehangatan, keteraturan dan dukungan yang selanjutnya dipasangkan dengan dimensi negatif yang menjadi lawan dari tiap dimensi positifnya sehingga memiliki enam subdimensi. Pada dimensi kehangatan, terdapat 2 subdimensi, yaitu subdimensi kehangatan dan penolakan (warmth-rejection). Berdasarkan hasil analisis untuk subdimensi kehangatan, lebih dari setengah mahasiswa mempersepsikan bahwa ayah dan ibunya sangat menunjukkan rasa cintanya $(69,6 \%$ dan $86,3 \%$ ), selalu menikmati waktu yang dihabiskan bersama $(52,9 \%$ dan $75,5 \%)$, selalu senang saat bertemu $(61,8 \%$ dan $80,4 \%)$, membuatnya merasa spesial (51\% dan 61,8\%). Namun, pada subdimensi penolakan terdapat mahasiswa yang mempersepsikan bahwa ayah dan ibunya sangat membuat merasa seperti tidak diinginkan $(82,4 \%$ dan $90,2 \%)$ dan selalu tidak puas terhadap apa yang dilakukan mahasiswa $(64,7 \%$ dan $60,8 \%)$.

Gaya pengasuhan dimensi selanjutnya adalah keteraturan, yang terdiri atas subdimensi keteraturan dan ketidakteraturan (structurechaos). Pada subdimensi keteraturan, mahasiswa memiliki persepsi bahwa ayah dan ibunya selalu memberikan bimbingan $(47,1 \%$ dan $46,1 \%$ ), memberikan penjelasan tentang suatu hal $(50,0 \%$ dan $54,9 \%)$, dan membantu mencarikan solusi permasalahan yang dihadapi $(41,2 \%$ dan $60,8 \%)$. Sementara itu, pada subdimensi ketidakteraturan, mahasiswa mempersepsikan ayah dan ibunya sering marah tanpa diketahui apa penyebabnya $(62,7 \%$ dan $63,7 \%)$ dan sering menghukum tanpa alasan $(87,3 \%$ dan $80,4 \%)$. Hasil penelitian menemukan bahwa dimensi dukungan yaitu lebih dari setengah mahasiwa mempersepsikan ayah dan ibunya sangat percaya pada mereka $(54,9 \%$ dan $63,7 \%)$, menerima apa adanya $(62,7 \%$ dan $69,6 \%)$, dan mendorong untuk jujur pada diri sendiri (63,7\% dan 69,6\%). Namun, mahasiswa juga menyatakan bahwa ayah dan ibunya sering berkata tidak untuk segala sesuatu $(54,9 \%$ dan $58,8 \%)$.

Tabel 1 Nilai minimum, maksimum, rata-rata, dan standar deviasi indeks tiga dimensi dan subdimensi gaya pengasuhan model positif

\begin{tabular}{|c|c|c|c|c|}
\hline \multirow{2}{*}{ Dimensi } & \multicolumn{2}{|c|}{ Ayah } & \multicolumn{2}{|c|}{ Ibu } \\
\hline & Min-Maks & Rata-rata $\pm S D$ & Min-Maks & Rata-rata $\pm S D$ \\
\hline Kehangatan & $33,33-95,83$ & $73,37 \pm 12,12$ & $45,83-95,83$ & $77,78 \pm 9,59$ \\
\hline (+) Kehangatan & $25,00-100,00$ & $82,93 \pm 18,63$ & $33,33-100,00$ & $90,85 \pm 13,85$ \\
\hline (-) Penolakan & $8,33-83,33$ & $36,19 \pm 14,67$ & $0,00-75,00$ & $35,29 \pm 14,27$ \\
\hline$p$ (value) & \multicolumn{4}{|c|}{0,004} \\
\hline Keteraturan & $29,17-100,00$ & $76,51 \pm 14,51$ & $45,83-100,00$ & $79,12 \pm 12,36$ \\
\hline (+) Keteraturan & $16,67-100,00$ & $75,00 \pm 21,37$ & $16,67-100,00$ & $79,66 \pm 17,42$ \\
\hline (-) Ketidakteraturan & $0,00-83,33$ & $21,98 \pm 17,27$ & $0,00-75,00$ & $21,4 \pm 16,89$ \\
\hline$p$ (value) & \multicolumn{4}{|c|}{0,168} \\
\hline Dukungan & $33,33-95,83$ & $70,18 \pm 11,74$ & $33,33-100,00$ & $70,87 \pm 12,32$ \\
\hline (+) Dukungan & $33,33-100,00$ & $81,45 \pm 18,57$ & $41,67-100,00$ & $86,02 \pm 14,98$ \\
\hline (-) Paksaan & $8,33-83,33$ & $41,09 \pm 18,25$ & $0,00-100,00$ & $44,28 \pm 21,01$ \\
\hline$p$ (value) & \multicolumn{4}{|c|}{0,681} \\
\hline $\begin{array}{l}\text { Total gaya pengasuhan model positif } \\
p \text { (value) }\end{array}$ & $34,72-88,89$ & 73,35 10,45 & $43,06-93,06$ & $75,92 \pm 8,89$ \\
\hline
\end{tabular}


Tabel 1 menunjukkan bahwa terdapat perbedaan nyata dan signifikan antara gaya pengasuhan ayah dan ibu, yaitu gaya pengasuhan ibu mempunyai skor rata-rata yang lebih tinggi dibandingkan dengan ayah. Selanjutnya, jika dianalisis berdasarkan dimensi gaya pengasuhan maka ditemukan adanya perbedaan nyata dan signifikan antara gaya pengasuhan ayah dan ibu pada dimensi kehangatan. Hal ini dapat disimpulkan bahwa rata-rata mahasiswa lebih merasakan kehangatan dari ibu dibandingkan dari ayah. Sementara itu, gaya pengasuhan dimensi keteraturan dan dukungan tidak menunjukkan adanya perbedaan signifikan.

Apabila dianalisis berdasarkan dimensi positif dan negatif, hasil penelitian pada Tabel 1 menunjukkan bahwa nilai rata-rata terbesar pada dimensi negatif gaya pengasuhan ayah dan ibu terdapat pada subdimensi paksaan. Selain itu, nilai rata-rata subdimensi negatif penolakan dan ketidakteraturan ayah lebih tinggi dari ibu. Pada dimensi positif juga terlihat bahwa nilai rata-rata gaya pengasuhan ibu lebih tinggi daripada ayah. Temuan ini menunjukkan bahwa mahasiswa menganggap ibu menerapkan gaya pengasuhan yang lebih baik daripada ayah.

\section{Karakter}

Seligman dan Peterson (2004) mengklasifikasikan 24 subdimensi ke dalam enam dimensi karakter. Subdimensi bijak terdiri dari nilai kebaikan kreatifitas, keingintahuan, justifikasi, cinta akan pembelajaran, dan perspektif. Subdimensi teguh hati mencakup nilai kebaikan berani, gigih, jujur, dan gairah. Subdimensi manusiawi mencakup nilai cinta, kebaikan, dan kecerdasan sosial. Subdimensi adil yaitu kerjasama tim, adil/sportif, dan kepemimpinan. Subdimensi sederhana terdiri dari nilai kebaikan memaafkan, kerendahan hati, bijaksana, dan pengaturan diri. Subdimensi transendensi mencakup penghargaan terhadap keindahan, rasa syukur, harapan, humor, dan spiritualitas.

Tabel 2 Nilai minimum, maksimum, rata-rata, dan standar deviasi indeks karakter

\begin{tabular}{lrr}
\hline Dimensi & \multicolumn{1}{c}{ Min-Maks } & Rata-rata \pm SD \\
\hline Bijak & $39,00-92,00$ & $65,96 \pm 9,67$ \\
Teguh hati & $51,25-90,00$ & $69,09 \pm 9,22$ \\
Manusiawi & $53,33-91,67$ & $71,34 \pm 8,85$ \\
Adil & $50,00-100,00$ & $72,07 \pm 9,93$ \\
Sederhana & $48,75-90,00$ & $64,50 \pm 8,01$ \\
Transendensi & $51,00-91,00$ & $73,70 \pm 8,92$ \\
\hline
\end{tabular}

Penelitian ini, seperti yang tersaji pada Tabel 2 , menemukan bahwa nilai rata-rata tertinggi karakter pada mahasiswa dalam penelitian ini terdapat pada dimensi transendensi $(73,70)$ dan paling rendah adalah pada dimensi sederhana $(64,50)$. Hal tersebut menujukkan bahwa mahasiwa tingkat pertama dalam penelitian ini memiliki karakter dominan pada apresiasi terhadap keindahan, rasa syukur, harapan, humor, dan spiritualitas. Namun cenderung kurang optimal pada karakter memaafkan, kerendahan hati, bijaksana, dan pengaturan diri. Meskipun begitu, apabila dilihat dari indeks rata-rata terlihat bahwa capaian karakter mahasiswa berkisar antara 64 hingga 74 yang menunjukkan adanya potensi untuk lebih ditingkatkan dan diasah kekuatan karakternya.

\section{Kepuasan Hidup}

Kepuasan hidup mahasiswa dalam penelitian ini meliputi kepuasan terhadap diri sendiri, teman, lingkungan tempat tinggal, dan pendidikan. Hasil penelitian menunjukkan bahwa lebih dari sepertiga mahasiswa memberikan jawaban puas terhadap diri sendiri $(38,2 \%)$, kesenangan yang dimiliki $(37,3 \%)$; kondisi kesehatan $(34,3 \%)$; teman $(36,3 \%)$; kehidupan sosial (38,3\%). Meskipun demikian, masih terdapat mahasiswa yang menyatakan sangat tidak puas hingga kurang puas terhadap diri sendiri $(10,8 \%)$; kesenangan yang dimiliki (6,9\%); kondisi kesehatan dan fisik (12,8\%); teman $(22,6 \%)$; dan kehidupan sosial (2,9\%). Sementara itu, hasil penelitian juga menunjukkan bahwa satu dari dua mahasiswa telah merasa puas dengan kehidupannya secara keseluruhan bahkan satu dari dua puluh mahasiswa sangat puas terhadap kehidupannya secara keseluruhan (Tabel 3).

Selanjutnya, terdapat 32,4 persen mahasiswa yang menyatakan sedikit puas terhadap jumlah yang waktu yang dimiliki. Sebanyak satu dari empat mahasiswa juga menyatakan sedikit puas terhadap capaian akademiknya (IP). Namun, masih terdapat mahasiswa yang merasa sangat tidak puas hingga kurang puas terhadap jumlah waktu yang dimiliki $(15,6 \%)$ dan capaian akademik $(26,4 \%)$. Adapun secara keseluruhan, lebih dari setengah mahasiswa $(53,9 \%)$ menyatakan puas terhadap kehidupannya (Tabel 3). Hasil analisis juga menunjukkan indeks rata-rata dari kepuasan hidup mahasiswa yaitu 58,26 dengan standar deviasi 10,73. Adapun indeks kepuasan hidup minimun yang diperoleh yaitu 33,33 dan indeks maksimum yaitu 83,33. 
Tabel 3 Sebaran mahasiswa berdasarkan persentase kepuasan hidup

\begin{tabular}{|c|c|c|c|c|c|c|c|}
\hline \multirow{2}{*}{ Pernyataan } & \multicolumn{7}{|c|}{$\%$} \\
\hline & 1 & 2 & 3 & 4 & 5 & 6 & 7 \\
\hline Diri Sendiri & 1,0 & 1,0 & 8,8 & 16,7 & 27,5 & 38,2 & 6,9 \\
\hline $\begin{array}{l}\text { Kesenangan yang } \\
\text { dimiliki }\end{array}$ & 0,0 & 0,0 & 6,9 & 16,7 & 27,5 & 37,3 & 11,8 \\
\hline $\begin{array}{l}\text { Jumlah waktu luang } \\
\text { yang dimiliki }\end{array}$ & 0,0 & 2,9 & 12,7 & 29,4 & 32,4 & 18,6 & 3,9 \\
\hline $\begin{array}{l}\text { Kondisi kesehatan dan } \\
\text { fisik }\end{array}$ & 0,0 & 1,0 & 11,8 & 18,6 & 20,6 & 34,3 & 13,7 \\
\hline Teman & 1,0 & 0,0 & 1,0 & 20,6 & 32,4 & 36,3 & 8,8 \\
\hline Kehidupan sosial & 0,0 & 0,0 & 2,9 & 21,6 & 33,3 & 38,2 & 3,9 \\
\hline Capaian akademik (IP) & 7,8 & 4,9 & 13,7 & 22,5 & 25,5 & 19,6 & 5,9 \\
\hline $\begin{array}{l}\text { Kehidupan secara } \\
\text { keseluruhan }\end{array}$ & 0,0 & 1,0 & 2,9 & 12,7 & 23,5 & 53,9 & 5,9 \\
\hline
\end{tabular}

Skor indeks rata-rata kepuasan mahasiswa yang hanya mencapai 58,26 menunjukkan bahwa rata-rata mahasiswa menilai dirinya belum terlalu puas dengan kehidupannya dalam keseluruhan aspek diri sendiri, teman, lingkungan tempat tinggal, pendidikan, dan keseluruhan kehidupannya. Kepuasan hidup mahasiswa yang masih belum tinggi dapat juga terjadi karena mereka baru saja meninggalkan kehidupan SMA dan mulai beradaptasi dengan kehidupan perguruan tinggi. Selain itu, penyesuaian tempat tinggal dalam bentuk asrama tentu saja menjadi aspek tersendiri yang membuat kepuasan mahasiswa menjadi belum maksimal.

\section{Pengaruh Karakteristik Mahasiswa, Karakteristik Keluarga, dan Gaya Pengasuhan terhadap Karakter}

Berdasarkan pengembangan model sesuai tujuan penelitian kedua yaitu menganalisis pengaruh variabel bebas terhadap karakter mahasiswa ditemukan model yang signifikan pada $p=0,035$ seperti yang tersaji pada Tabel 4. Model regresi yang ditemukan menunjukkan bahwa gaya pengasuhan ayah $(B=0,336$; $p=0,001$ ) berpengaruh positif sangat signifikan terhadap karakter mahasiswa. Koefisien regresi menunjukkan bahwa setiap kenaikan satu satuan gaya pengasuhan ayah akan menaikkan karakter mahasiswa sebesar 0,336 poin. Nilai Adjusted $R$-square model yang tersaji pada Tabel 4 adalah sebesar 0,105 yang menunjukkan bahwa variabel bebas dalam model hanya menjelaskan 10,5 persen pengaruhnya terhadap karakter sedangkan 89,5 persen sisanya dipengaruhi oleh variabel bebas lain yang tidak diteliti. Adapun variabel lain yaitu karakteristik mahasiswa (usia, jenis kelamin), karakteristik keluarga (usia ayah dan ibu, status pekerjaan ayah dan ibu, lama pendidikan ayah dan ibu, pendapatan keluarga, besar keluarga), dan gaya pengasuhan ibu tidak ditemukan berpengaruh signifikan terhadap karakter mahasiswa.

Tabel 4 Hasil analisis regresi linear pada karakteristik mahasiswa dan keluarga serta gaya pengasuhan terhadap karakter

\begin{tabular}{|c|c|c|c|}
\hline Variabel Bebas & $\mathrm{B}$ & $\beta$ & Sig. \\
\hline Konstanta & 45,823 & & 0,037 \\
\hline $\begin{array}{l}\text { Usia mahasiswa } \\
\text { (tahun) }\end{array}$ & 0,783 & 0,076 & 0,445 \\
\hline $\begin{array}{l}\text { Jenis kelamin } \\
(0=\text { laki-laki; } \\
1=\text { perempuan })\end{array}$ & $-2,473$ & $-0,153$ & 0,127 \\
\hline Usia ayah (tahun) & 0,025 & 0,019 & 0,900 \\
\hline Usia ibu (tahun) & $-0,044$ & $-0,030$ & 0,853 \\
\hline $\begin{array}{l}\text { Status pekerjaan } \\
\text { ayah }(0=\text { tidak } \\
\text { bekerja; } 1=\text { bekerja })\end{array}$ & $-7,764$ & $-0,168$ & 0,123 \\
\hline $\begin{array}{l}\text { Status pekerjaan } \\
\text { ibu }(0=\text { tidak } \\
\text { bekerja; } 1=\text { =bekerja })\end{array}$ & $-1,381$ & $-0,088$ & 0,423 \\
\hline $\begin{array}{l}\text { Lama pendidikan } \\
\text { ayah (tahun) }\end{array}$ & $-0,424$ & $-0,228$ & 0,184 \\
\hline $\begin{array}{l}\text { Lama pendidikan } \\
\text { ibu (tahun) }\end{array}$ & 0,038 & 0,018 & 0,915 \\
\hline $\begin{array}{l}\text { Pendapatan } \\
\text { keluarga } \\
\text { (rupiah/bulan) }\end{array}$ & $5,512 \mathrm{E}^{-8}$ & 0,030 & 0,802 \\
\hline $\begin{array}{l}\text { Besar keluarga } \\
\text { (orang) }\end{array}$ & $-0,429$ & $-0,090$ & 0,402 \\
\hline $\begin{array}{l}\text { Gaya pengasuhan } \\
\text { ayah (indeks) }\end{array}$ & 0,336 & 0,448 & $0,001^{* *}$ \\
\hline $\begin{array}{l}\text { Gaya pengasuhan } \\
\text { ibu (indeks) }\end{array}$ & 0,011 & 0,013 & 0,915 \\
\hline $\mathrm{R}^{2}$ & & 0,211 & \\
\hline Adjusted $\mathrm{R}^{2}$ & & 0,105 & \\
\hline $\mathrm{F}$ & & 1,982 & \\
\hline Sig. & & 0,035 & \\
\hline
\end{tabular}


Tabel 5 Hasil analisis regresi linear pada karakteristik mahasiswa, karakteristik ayah, gaya pengasuhan ayah dan ibu, serta karakter mahasiswa terhadap kepuasan hidup

\begin{tabular}{|c|c|c|c|c|c|c|}
\hline \multirow{2}{*}{ Variabel bebas } & \multicolumn{3}{|c|}{ Kepuasan hidup } & \multicolumn{3}{|c|}{ Kepuasan hidup } \\
\hline & $B$ & $\beta$ & Sig. & B & $\beta$ & Sig. \\
\hline Konstanta & 12,162 & & 0,689 & 3,119 & & 0,918 \\
\hline Usia mahasiswa (tahun) & $-0,291$ & $-0,021$ & 0,836 & $-0,038$ & $-0,003$ & 0,978 \\
\hline $\begin{array}{l}\text { Jenis kelamin }(0=\text { laki-laki; } \\
1=\text { perempuan })\end{array}$ & $-0,718$ & $-0,033$ & 0,743 & $-0,954$ & $-0,043$ & 0,663 \\
\hline Usia ayah (tahun) & 0,211 & 0,118 & 0,236 & 0,279 & 0,138 & 0,174 \\
\hline $\begin{array}{l}\text { Status pekerjaan ayah ( } 0=\text { tidak } \\
\text { bekeria: } 1=\text { bekeria) }\end{array}$ & $-1,213$ & $-0,019$ & 0,851 & $-0,482$ & $-0,022$ & 0,833 \\
\hline Lama pendidikan ayah (tahun) & 0,026 & 0,010 & 0,930 & 0,358 & 0,122 & 0,291 \\
\hline $\begin{array}{l}\text { Pendapatan keluarga } \\
\text { (rupiah/bulan) }\end{array}$ & $3,548 \times 10^{-7}$ & 0,142 & 0,229 & $1,979 \times 10^{-7}$ & 0,079 & 0,485 \\
\hline $\begin{array}{l}\text { Besar keluarga (orang) } \\
\text { Gava pengasuhan avah (indeks) }\end{array}$ & $\begin{array}{l}1,031 \\
0,116\end{array}$ & $\begin{array}{l}0,157 \\
0,096\end{array}$ & $\begin{array}{l}0,140 \\
0,347\end{array}$ & 0,918 & 0,140 & 0,174 \\
\hline n ibu (indeks) & & & & 0,088 & 0,073 & 0,472 \\
\hline Karakter (indek & 0,385 & 0,281 & $0,006^{\star \star}$ & 0,394 & 0,288 & $0,005^{\star \star}$ \\
\hline$R^{2}$ & & 0,160 & & & 0,174 & \\
\hline Adjusted $\mathrm{R}^{2}$ & & 0,077 & & & 0,094 & \\
\hline & & 1,940 & & & 2,158 & \\
\hline Sig. & & 0,056 & & & 0,032 & \\
\hline
\end{tabular}

Keterangan: ${ }^{*}$ signifikan pada $p<0.05 ;{ }^{* *}$ signifikan pada $p<0,01$

\section{Pengaruh Karakteristik Mahasiswa, Karakteristik Keluarga, Gaya Pengasuhan, dan Karakter terhadap Kepuasan Hidup Mahasiswa}

Penelitian ini menemukan model yang tidak signifikan dalam uji pengaruh linear berganda untuk melihat pengaruh karakterisik mahasiswa, karakteristik keluarga, gaya pengasuhan, dan karakter terhadap kepuasan hidup mahasiswa dengan memasukkan semua variable bebas dalam satu model. Oleh karena itu, uji regresi ini terbagi menjadi dua model yang terpisah antara gaya pengasuhan ayah (model 1) dan gaya pengasuhan ibu (model 2). Kedua model seperti yang tersaji pada Tabel 5 menunjukkan bahwa gaya pengasuhan orang tua kurang memberikan pengaruh terhadap kepuasan hidup mahasiswa dibandingkan karakter.

Nilai Adjusted $R$-square pada model regresi pertama adalah 0,077 , artinya bahwa model tersebut hanya mewakili 7,7 persen pengaruh variabel-variabel bebas dalam model terhadap karakter mahasiswa sedangkan 92,3 persen sisanya dipengaruhi oleh variabel bebas lain yang tidak diteliti. Hasil uji pengaruh pada model ke-1 menunjukkan bahwa karakter mahasiswa berpengaruh signifikan dan positif terhadap kepuasan mahasiswa $(B=0,385$; $p=0,006)$. Hal ini berarti setiap kenaikan satu satuan karakter mahasiswa akan menaikkan kepuasan hidup mahasiswa sebesar 0,385.

Hasil yang sama ditemukan pada model ke-2, yaitu variabel yang memiliki pengaruh signifikan dan positif terhadap kepuasan hidup mahasiswa adalah karakter mahasiswa $(B=0,394 ; \quad p=0,005)$ yang artinya setiap kenaikan satu satuan karakter mahasiswa akan menaikkan kepuasan hidup mahasiswa sebesar 0,394. Nilai Adjusted R-square pada model regresi kedua sebesar 0,094 yang menunjukkan bahwa model tersebut hanya mewakili 9,4 persen pengaruh variabelvariabel bebas dalam model terhadap karakter mahasiswa sedangkan 90,6 persen sisanya dipengaruhi oleh variabel bebas lain yang tidak diteliti (Tabel 5).

\section{PEMBAHASAN}

Penelitian ini membuktikan bahwa ayah dan ibu lebih dominan menggunakan gaya pengasuhan keteraturan (structure) pada anaknya. Orang tua cenderung lebih memberikan arahan, bimbingan, atau petunjuk setiap berinteraksi dengan anak. Hal ini mendukung pernyataan Nurhidayah (2008) yang mengatakan bahwa perhatian, bimbingan, dan pengawasan perlu dilakukan orang tua agar anak tidak mengalami dampak negatif dari permasalahan yang dimilikinya. Hasil penelitian juga menemukan bahwa mahasiswa lebih merasakan adanya kehangatan, keteraturan, dan dukungan dari ibu dibandingkan kehangatan, keteraturan, dan dukungan yang diberikan ayah. Hasil ini mendukung pernyataan bahwa ibu dinilai lebih memberikan kasih sayang dalam bentuk sentuhan, peluk, dan mengajak bicara (Verauli, 2012 dalam Rahman \& Yusuf, 2012). Hasil ini juga mendukung temuan Papilia (2008) dalam Dewi dan Basti (2015) yang menyatakan bahwa anak menaruh kepercayaan yang besar 
pada ibunya dan ibu secara naluriah akan memberikan rasa aman dan nyaman yang mengacu pada dimensi kehangatan dalam pengasuhan. Selain itu, penyebab mahasiswa lebih merasakan kehangatan, keteraturan, dan dukungan dari ibu karena sebagian besar ibu tidak bekerja/ibu rumah tangga yang memiliki kemungkinan waktu yang lebih banyak di rumah dibandingkan ayah. Penelitian ini mendukung temuan Krisnatuti dan Putri (2012) yang menyatakan bahwa kurangnya waktu yang dihabiskan bersama anak akan mengubah hubungan yang terjalin. Hal ini menyebabkan persepsi anak cenderung menganggap ibu lebih memberikan kehangatan, aturan, dan dukungan daripada ayah yang lebih banyak menghabiskan waktu di luar rumah. Temuan lain dalam penelitian ini adalah paksaan merupakan cara negatif yang dominan dilakukan ayah dan ibu dalam berinteraksi dengan anak serta ditemukan bahwa mahasiswa menganggap ayahnya lebih sering melakukan penolakan dan kurang memberi arahan. Hal ini disebabkan dominan ayah yang bekerja sehingga hanya memiliki waktu yang lebih sedikit dengan anaknya. Suryaputri, Rosha, dan Anggraeni (2014) menyatakan orang tua yang bekerja memiliki alokasi waktu lebih sedikit untuk anak sehingga kualitas interaksi dengan anak kurang optimal.

Sementara itu, hasil penelitian menemukan juga bahwa karakter yang dominan dimiliki mahasiswa terdapat pada dimensi transendensi yang meliputi karakter apresiasi terhadap keindahan dan kesempurnaan, bersyukur, harapan, humor, dan spiritualitas. Hasil penelitian ini mendukung hasil penelitian Fahmi dan Ramdani (2014) yang menemukan bahwa karakter yang paling dominan dimiliki mahasiswa adalah harapan, bersyukur, dan spiritualitas.

Hasil dari uji pengaruh menunjukkan bahwa hanya gaya pengasuhan ayah berpengaruh positif signifikan terhadap karakter mahasiswa. Penelitian yang dilakukan Nurhidayah (2008) membuktikan bahwa keterlibatan ayah dalam pengasuhan berpengaruh positif dengan perkembangan anak. Selain itu, pada hasil uji pengaruh terhadap kepuasan hidup mahasiswa ditemukan bahwa hanya karakter mahasiswa yang dapat memengaruhi kepuasan hidup mahasiswa. Hal ini didukung oleh West (2006) yang mengatakan bahwa karakter seseorang dapat memengaruhi bagaimana kepuasan diri terhadap hidupnya. Penelitian Park, Peterson, dan Seligman (2004) juga membuktikan bahwa semakin tinggi karakter seseorang maka semakin tinggi kepuasan hidup yang dirasakannya. Sejalan dengan temuan Madahi, Liaghat, dan Madah (2013) yang membuktikan bahwa gaya pengasuhan orang tua dapat memengaruhi karakter pengaturan diri pada anak

Penelitian ini juga membuktikkan bahwa kehangatan, keteraturan, dan dukungan dari ayah secara tidak langsung dapat memengaruhi kepuasan hidup mahasiswa melalui karakter yang terbentuk dari pengasuhan; mengingat karakter secara langsung memberikan pengaruh yang lebih nyata terhadap kepuasan mahasiswa tingkat pertama. Sejalan dengan Nurhidayah (2008) yang membuktikkan bahwa peningkatan prestasi belajar anak didapatkan dari peran ayah dalam memotivasi anaknya. Hal ini dapat disimpulkan bahwa saat anak termotivasi oleh ayahnya, anak cenderung akan membentuk suatu perilaku untuk mencapai tujuan tersebut yang pada akhirnya akan didapatkan hasil pencapaian anak yang optimal termasuk prestasi belajar (Nurhidayah, 2008). Temuan ini menegaskan bahwa pada mahasiswa tingkat pertama yang kemudian harus tinggal di asrama, kebiasaan-kebiasaan positif yang telah terbangun dari rumah dan keluarganya khususnya contoh dari ayah, akan menjadi modal penting untuk menumbuhkan karakter positif dalam dirinya sehingga ketika harus hidup mandiri mahasiswa akan lebih memaknai kehidupannya dengan lebih positif. Makna positif tentang hidupnya selanjutnya akan membentuk kepuasan mahasiswa terhadap kehidupannya.

Keterbatasan dari penelitian ini adalah hanya berkonsentrasi terhadap dua variabel yang memengaruhi kepuasan hidup mahasiswa tingkat pertama, yaitu gaya pengasuhan dan karakter. Oleh karenanya, perlu diteliti lebih lanjut mengenai faktor-faktor kepuasan hidup seseorang seperti penelitian Coutinho dan Woolery (2004) yang meneliti kepuasaan hidup mahasiswa dengan mengukur kebutuhan akan pengetahuan (need for cognition) atau kepuasan hidup yang dicapai melalui karakternya yang dipengaruhi oleh interaksi orang tua dan anak dan juga aspek keterlibatan ayah (engagement, accessibility, dan responsibility).

\section{SIMPULAN DAN SARAN}

Hasil penelitian menunjukkan bahwa peningkatan pemberian kehangatan, keteraturan, dan dukungan khususnya dari ayah akan lebih nyata dalam meningkatkan 
kualitas karakter mahasiswa tingat pertama yang tinggal di asrama sebagai sebuah tahapan baru dalam kehidupannya yang lebih mandiri. Temuan tersebut menegaskan bahwa gaya pengasuhan ayah dengan adanya kehangatan, keteraturan, dan dukungan pada anak memengaruhi perkembangan karakter anak yang lebih baik. Selanjutnya, karakter mahasiswa mempunyai pengaruh yang lebih nyata dan langsung terhadap kepuasan hidup mahasiswa dibandingkan dengan gaya pengasuhan. Oleh karenanya, temuan tersebut mengindikasikan bahwa gaya pengasuhan dapat memengaruhi kepuasan hidup mahasiswa tingat pertama yang tinggal di asrama melalui karakter anak yang terbentuk sejak kecil.

Karakter seseorang merupakan bentukan dari proses sosialisasi dengan lingkungan, terutama yang didapatkan dari keluarga sedari kecil melalui gaya pengasuhan. Berdasarkan hasil penelitian yang membuktikan bahwa karakter dipengaruhi oleh gaya pengasuhan ayah maka diharapkan para ayah ikut terlibat dalam mengasuh anak (co-parenting) sehingga karakter yang terbentuk pada anak akan berkembang secara optimal.

Selain itu, kepuasan hidup merupakan hal yang penting untuk diketahui setiap individu. Mahasiswa khususnya yang sedang mengalami masa peralihan dari remaja ke dewasa tentunya memiliki tuntutan yang dapat menimbulkan stres/depresi. Oleh karenanya, kepuasan hidup menjadi hal yang perlu diukur untuk mengevaluasi diri dan menghindarikan diri dari stres/depresi karena seseorang dapat mengetahui aspek mana yang belum optimal di hidupnya. Hasil penelitian membuktikan bahwa kepuasan hidup dipengaruhi oleh karakter individu sehingga mahasiswa disarankan dapat mengoptimalkan seluruh karakter yang dimilikinya agar tercapainya kepuasan hidup yang lebih tinggi.

\section{DAFTAR PUSTAKA}

Amelia, J. (2013). Asosiasi antara gaya pengasuhan dan status identitas diri remaja etnis jawa. Calyptra, 2(1), 2-14.

Asih, N. S., Yuliadi, I. \& Karyanta, N. A. (2015). Hubungan antara konsep diri dan religiusitas dengan kepuasan hidup pada lansia di Desa Rendeng, Kabupaten Kudus. Jurnal IImiah Psikologi Candrajiwa. 4(1), 28-39.

Coutinho, S. A., \& Woolery, L. M. (2004). The need for cognition and life satisfaction among college students. College Student Journal, 38(2), 203-206.

Chung, H. (2008). Resiliency and character strengths among college students. (Disertasi). The University of Arizona, Tucson, Amerika Serikat.

Dalmeri. (2014). Pendidikan untuk pengembangan karakter (telaah terhadap gagasan Thomas Lickona dalam educating for character). Al-Ulum, 14(1), 269-288.

Dewi, L. A. K., \& Hamidah. (2013). Hubungan antara kesepian dengan ide bunuh diri pada remaja dengan orang tua yang bercerai. Jurnal Psikologi Klinis dan Kesehatan Mental, 2(3), 24-33.

Dewi, E. M. P., \& Basti. (2015). Pengaruh ibu berkarir dan internalisasi nilai karir pada remaja. JIPT, 3(1), 165-183.

Ehrlich, B. S., \& Isaacowitz, D. M. (2002). Does subjective well-being increase with age?. Perspectives in Psychology, 2026.

Fahmi, I., \& Ramdani, Z. (2014). Profil karakter dan kebajikan pada mahasiswa berprestasi. Psympathic, 1(1), 98-108.

Gogolinski, T. B. (2012). Effects of differences in parenting styles on couple distress and children's perceptions of family support (Thesis). University of Maryland, College Park, Amerika Serikat.

Hastuti D. 2014. Pengasuhan: Teori dan Prinsip serta Aplikasinya di Indonesia. Bogor: IPB Press.

Hurlock, E. B. (2009). Psikologi perkembangan. Jakarta, ID: Erlangga.

Krisnatuti, D., \& Muharrifah, A. (2010). Interaksi antara remaja, ayah, dan sekolah serta hubungannya dengan tingkat stres dalam menghadapi ujian nasional pada siswa SMA. Jurnal IImu Keluarga dan Konsumen, 3(1), 18-26. http://dx.doi.org/10.24156/jikk.2010.3.1.1 8.

Krisnatuti, D., \& Putri, H. A. (2012). Gaya pengasuhan orang tua, interaksi, serta kelekatan ayah-remaja, dan kepuasan ayah. Jurnal Ilmu Keluarga dan Konseumen, 5(2), 101-109.

Madahi, M. E., Liaghat, R., \& Madah, L. (2013). Study of the effects of parenting styles and self-regulation on academic achievment. IRJABS, 4(1), 19-24. 
Nisfiannor, M. M., Rostiana, \& Puspasari, T. (2004). Hubungan antara komitmen beragama dan subjective well-being pada remaja akhir di Universitas Tarumanegara. Jurnal Psikologi, 2(1), 74-92.

Nurhidayah, S. (2008). Pengaruh ibu bekerja dan peran ayah dalam coparenting terhadap prestasi belajar anak. Jurnal Soul, 1(2), 1-14.

Papalia, D. E., Olds, S. W., \& Feldman, R. D. (2009). Human development (perkembangan manusia). Marswendy $\mathrm{B}$, penerjemah; Widyaningrum $\mathrm{R}$, editor. Ed ke-10. Jakarta, ID: Salemba Humanika.

Park, N., Peterson, C., \& Seligman, M. E. P. (2004). Strengths of character and well being. Journal o $f$ Social and Clinical Psychology, 23(5), 603-619.

Pasaribu, R. M., Hastuti, D., \& Alfiasari. (2013). Gaya pengasuhan permisif dan rendahnya sosialisasi nilai dalam keluarga beresiko terhadap penurunan karakter remaja. Jurnal IImu Keluarga \& Konsumen, $\quad 6(3), \quad$ 163-171. http://dx.doi.org/10.24156/jikk.2013.6.3.1 63.
Rahman, P. L., \& Yusuf, E. A. (2012). Gambaran pola asuh orang tua pada masyarakat pesisir pantai. PREDICARA, 1(1), 21-36.

Seligman \& Peterson, C. (2004). Character strengths and virtues. New York, US: Oxford University Press.

Skinner, E., Sandy, J., \& Tatiana, S. (2005). Six dimensions of parenting: a motivational model. Parenting: Science and Practice, 5(2), 175-235.

Suryaputri, I. Y., Rosha, B. C., \& Anggraeni, D. (2014). Determinan kemampuan motorik anak berusia 2-6 tahun: studi kasus di Kelurahan Kebon Kalapa Bogor. Penel Gizi Makan, 37(1), 43-50.

West, N. M. (2006). The relationship among personality traits, character strengths, and life satisfaction in college students. (Disertasi). The University of Tennesse, Knoxville, Amerika Serikat.

Wijayanti, H., \& Nurwian, F. (2010). Karakter dan kebahagiaan pada suku jawa. Jurnal Psikologi, 3(2), 114-122.

[WHO] World Health Organization. (2014). Preventing suicide, a global imperative. Geneve, Switzerland: WHO Press. 